\title{
Short communication \\ Risk factors with the occurrence of parasites and coliform in vegetables from an agroindustry
}

\author{
Francisco Rafael Martins Soto ${ }^{1 *}$, Jéssica Vilela da Cruz ${ }^{1}$, Laine Rodrigues Lima ${ }^{1}$, \\ Iolanda Cristina Silveira Duarte ${ }^{2}$, Sandro Eugênio Pereira Gazzinelli ${ }^{1}$, Sérgio Santos de Azevedo ${ }^{3}$
}

$10.1590 / 0034-737 X 201865010012$

\begin{abstract}
In this study, we evaluated the risk factors associated with the occurrence of total coliforms, thermotolerant coliforms, and intestinal parasite eggs in vegetables from an agroindustry in the city of Ibiúna-SP, Brazil. A questionnaire with 17 questions was applied to 24 producers to carry out a diagnosis of the risk factors and their posterior association or not with total coliforms, thermotolerant coliforms, and intestinal parasite eggs. The questions addressed mainly the production system, fertilizer used, source of the water used for irrigation, sanitization of the vegetables, and form of transport. For the investigation of total coliforms, thermotolerant coliforms, and intestinal parasite eggs, the samples were processed at the microbiology and parasitology laboratory of the Federal Institute of São Paulo, São Roque Campus. The results revealed that total coliforms were found in $100 \%$ of the investigated samples and thermotolerant coliforms were detected in $95.83 \%$ of the samples. There was a significant statistical association for the risk factor use of reservoir water, where there was release of wastewater and absence of sanitization of the vegetables at the moment of harvest in relation to the presence of thermotolerant coliforms. Intestinal parasite eggs were found in $33.33 \%$ of the samples.
\end{abstract}

Key words: good production practices; producers; contaminated water; sanitization.

\section{RESUMO}

\section{Fatores de risco e a ocorrência de parasitas e coliformes em hortaliças de uma agroindústria}

Avaliou-se neste trabalho os fatores de risco associados com a ocorrência de coliformes totais (CT), coliformes fecais $(\mathrm{CF})$ e ovos de parasitas intestinais (OPI) em hortaliças que chegavam a uma agroindústria do município de Ibiúna- SP. Foi aplicado um questionário com 17 questões para 24 produtores a fim de realizar o diagnóstico dos fatores de risco e a sua posterior associação com a presença ou não de CT, CF e OPI. As questões versavam principalmente sobre o sistema de produção, adubo empregado, origem da água utilizada para irrigação, higienização das hortaliças e forma de transporte. Para a pesquisa de CT, CF e OPI, as amostras foram processadas no laboratório de microbiologia e parasitologia do Instituto Federal de São Paulo, campus São Roque. Os resultados revelaram que em 100\% das amostras investigadas foram encontrados CT, e em 95,83\%, detectados CF. Houve associação estatística significante para o fator de risco utilização de água de açude onde havia lançamento de águas residuais e ausência de higienização de hortaliça no ato da colheita em relação a presença de CF. Ovos de parasitas intestinais foram encontrados em 33,33\% das amostras.

Palavras chave: boas práticas de produção; produtores; água contaminada; higienização.

\footnotetext{
Submetido em 16/11/2015 e aprovado em 07/11/2017.

${ }^{1}$ Instituto Federal de Educação, Ciência e Tecnologia de São Paulo, São Roque, São Paulo, Brasil. chicosoto34@gmail.com; jessica.vilela5@gmail.com; laine.tecnoambiental@gmail.com ${ }^{2}$ Universidade Federal de São Carlos, Sorocaba, São Paulo, Brasil. iolanda.duarte@gmail.com

${ }^{3}$ Universidade Federal de Campina Grande, Campina Grande, Paraíba, Brasil. sandrogazzinelli@ hotmail.com

*Autor para correspondência: chicosoto34@gmail.com
} 


\section{INTRODUCTION}

Vegetables are an essential part of the world's population diet (Costa \& Oliveira, 2011). In Brazil, the average consumption is of $50 \mathrm{~kg}$ per habitant/year (Teixeira et al., 2006).

Currently, there has been an increase in the concern with the sanitary quality of vegetables consumed by the population, as well the practices used to produce them, and the use of technologies aiming at the environment preservation (Oliveira et al., 2014).

It can be said that there are two large groups of vegetable producers: those who will be able to adapt and meet the new sanitary requirements and will be competitive and those who will be marginalized in the process for not following the sanitary and environmental norms (Costa et al., 2011).

Among the set requirements, the maintenance of good production practices, from the cultivation of the vegetables to its commercialization to the final consumer aiming to reduce or eliminate the presence of total coliforms (TC), thermotolerant coliforms ( $\mathrm{TtC}$ ), and intestinal parasites eggs (IPE) in vegetables, mainly those which are consumed raw, takes on economical and public health importance (Silva et al., 2014).

The water contaminated by fecal matter of human or animal origin used in the irrigation of the vegetable gardens, the presence of infected handlers, inadequate sanitization, and transport practices are factors which have been pointed out as causes of contamination by $\mathrm{TC}, \mathrm{TtC}$, and IPE in vegetables (Carvalho et al., 2003; Beraldo \& Farache Filho, 2012). The investigation of TC, TtC, and IPE in vegetables is important in the public health area, especially considering the production, storing, transport, handling, and commercialization stages of these products (Ferreira et al., 2013). The prevalence and the food-borne infections by TC, TtC, and IPE caused by the ingestion of raw vegetables have been frequently reported (Silva, et al., 2011; França et al., 2013).

This work aimed to evaluate the risk factors associated with the occurrence of TC, $\mathrm{TtC}$, and IPE in vegetables from an agroindustry in the city of Ibiúna - SP, Brazil.

\section{MATERIAL AND METHODS}

The work was carried out in a vegetable processing agroindustry located in the in Ibiúna - SP, in the period from 25th August to 7th December 2014.

To perform the diagnosis of the risk factors and their posterior association with the presence or not of $\mathrm{TC}, \mathrm{TtC}$, and IPE, a questionnaire with 17 closed questions was initially applied to 24 vegetable producers who deliver their products to the agroindustry. The questions addressed the following areas: production system, type of fertilizer used, origin of the water used for irrigation, sanitization of the vegetables, and the form of transport used to the agroindustry.

For the investigation of $\mathrm{TC}, \mathrm{TtC}$, and IPE, a collection was carried out at the moment each producer was delivering the vegetables, without any processing at the agroindustry. To compose the analysis sample, between 15 and 20 vegetable leaves were collected randomly in aseptic conditions, from various boxes delivered by the producer. The samples were stored in aseptic polyethylene packages and transported the same day under refrigeration. Posteriorly, they were processed in the microbiology and parasitology laboratory of the Federal Institute of Education, Science and Technology of São Paulo, São Roque campus. The analysis of $\mathrm{TC}$ and $\mathrm{TtC}$ were carried out using the technique of Vanderzant \& Splittstoesser (1992) and Silva et al. (2007). The samples were diluted from the dilution of $10^{-1}, 10 \mathrm{~mL}$ of the samples were plated in three tubes containing $10 \mathrm{~mL}$ of Lauryl broth with double concentration with inverted Durhan tubes, $1.0 \mathrm{~mL}$ of the sample in three tubes with $10 \mathrm{~mL}$ of Lauryl broth with simple concentration, and $0.1 \mathrm{~mL}$ in tubes with $10 \mathrm{~mL}$ of Lauryl with simple concentration.

The tubes were incubated at $35 \pm 1^{\circ} \mathrm{C}$ for $24-48 \mathrm{~h}$. After this period, Durhan tubes which presented gas in their interior were considered as positive and compared to the combinations present in the Most Probable Number (MPN) table for TC. The investigation and counting of $\mathrm{TtC}$ with the use of inoculation loop aliquots were taken from the positive tubes and reprocessed to a tube containing $10 \mathrm{~mL}$ of EC broth also containing inverted Durhan tubes in a kiln at $45 \pm 2{ }^{\circ} \mathrm{C} / 24-48 \mathrm{~h}$. After this period, the presence of $\mathrm{TtC}$ was confirmed by the formation of gas in the Durhan tube and compared to the MPN table for TtC.

For the verification of the presence or not of IPE in the vegetables, the spontaneous sedimentation technique was used (Hoffman et al., 1934). Two hundred and fifty milliliters of distilled water were added to the samples, being these posteriorly filtered in four-fold gauze and left to rest for 24 $\mathrm{h}$. The following day, the supernatant liquid was discarded and about $30 \mathrm{~mL}$ of remaining were transferred to a $50-\mathrm{mL}$ sedimentation calix.

From the sediment obtained from the final part of the tube, three drops were collected with the aid of a plastic pipette and then placed between glass slides. When necessary, to differentiate protozoan cysts, lugol was added to the analyzed sample. Each sample was analyzed in triplicate, in an optical microscope, at 10x magnification, and a scanning was performed to find and identify the parasites. The confirmation of the parasitic structures was carried out using a 40x magnification. The parasitic forms were identified by using the parasitological classification key (OMS, 1991).

For the risk factor analysis, an univariable analysis was performed by using nonparametric tests to compare 
proportions (Chi-square or Fisher's exact tests), with a 5\% significance level (Zar, 1999). The analysis was carried out with the software SPSS for Windows, version 20.0.

\section{RESULTS AND DISCUSSION}

Of the 24 producers investigated, $16(66.66 \%)$ practiced conventional agriculture; four (16.66\%), hydroponic agriculture; three $(12.5 \%)$, conventional and hydroponic agriculture; and one (4.16\%), organic agriculture

Table 1 presents the results regarding the investigated risk factors for the presence of $\mathrm{TC}, \mathrm{TtC}$, and IPE in vegetables from 24 producers in the municipality of Ibiúna - SP.

Tables 2, 3, and 4 present the results regarding the association analysis for the risk factors and the respective $\mathrm{P}$-values for total coliforms, $\mathrm{TtC}$, and IPE.
For the risk use of non-treated organic fertilizer, more than half of the investigated producers $(54.2 \%)$ had this practice (Table 1). Silva et al. (2011), also evaluating the use of organic fertilizer and the sanitary quality of vegetables produced in Catu and Alagoinhas, in the State of Bahia, detected that, respectively, 100 and $80 \%$ of the producers used this type of fertilization in their vegetable gardens. These types of non-treated organic fertilizers used by the horticulturists may be characterized as means of contamination for the vegetables. However, Machado et al. (2006) highlighted that the fertilizer is not a determining factor for a possible contamination, also confirmed in this present work, in which there was no statistical association with the use of non-treated organic fertilizer and the occurrence of TC, TtC, and IPE (Tables 2, 3 and 4).

Table 1: Number of producers (NP) and the respective obtained percentage (\%) which presented risk factor associated to the presence of thermotolerant and total and intestinal parasite eggs in the vegetables from a total of 24 samples investigated

\begin{tabular}{ll}
\hline Risk factor & $\mathbf{N P / \%}$ \\
\hline Use of non-treated organic fertilizer & $13 / 54.2$ \\
Use of reservoir or river water for irrigation with a close septic tank & $05 / 20.8$ \\
Use of reservoir or river water for irrigation where there is release of wastewater & $08 / 33.3$ \\
Absence of sanitization in the harvesting of vegetables & $11 / 45.8$ \\
Absence of individual sanitization of vegetable with chlorinated water & $24 / 100$ \\
Transport in non-sanitized wooden box & $02 / 8.33$ \\
Transport in non-sanitized plastic box & $19 / 79.16$ \\
Transport in a truck with a wooden truck body & $10 / 41.66$ \\
\hline
\end{tabular}

Table 2: Association analysis for the risk factors and the respective P-values for total coliforms (TC)

\begin{tabular}{|c|c|c|c|c|}
\hline & \multirow{2}{*}{ Category } & \multirow{2}{*}{$\begin{array}{c}\text { Number } \\
\text { of producers }\end{array}$} & \multicolumn{2}{|l|}{ TC } \\
\hline & & & $>8(\%)$ & $\mathbf{p}$ \\
\hline \multirow{2}{*}{ Use of non-treated organic fertilizer } & No & 16 & 62.5 & \multirow{2}{*}{0.352} \\
\hline & Yes & 08 & 87.5 & \\
\hline \multirow{2}{*}{ Use of reservoir or river water for irrigation with a close septic tank } & No & 19 & 63.2 & \multirow{2}{*}{0.272} \\
\hline & Yes & 05 & 100 & \\
\hline \multirow{2}{*}{ Use of reservoir or river water for irrigation where there is release of wastewater } & No & 16 & 68.8 & \multirow{2}{*}{1.000} \\
\hline & Yes & 08 & 75 & \\
\hline \multirow{2}{*}{ Absence of sanitization in the harvesting of vegetables } & No & 13 & 53.8 & \multirow{2}{*}{0.078} \\
\hline & Yes & 11 & 90.9 & \\
\hline \multirow{2}{*}{ Absence of individual sanitization of vegetable with chlorinated water } & No & 24 & 73.7 & \multirow{2}{*}{0.608} \\
\hline & Yes & 00 & 60 & \\
\hline \multirow{2}{*}{ Transport in non-sanitized wooden box } & No & 22 & 72.7 & \multirow{2}{*}{0.507} \\
\hline & Yes & 02 & 50 & \\
\hline \multirow{2}{*}{ Transport in non-sanitized plastic box } & No & 05 & 80 & \multirow{2}{*}{1.000} \\
\hline & Yes & 19 & 68.4 & \\
\hline \multirow{2}{*}{ Transport in a truck with a wooden truck body } & No & 14 & 71.4 & \multirow{2}{*}{1.000} \\
\hline & Yes & 10 & 70 & \\
\hline
\end{tabular}


Water for irrigation with a septic tank and with the release of wastewater represented 20.8 and $33.3 \%$, respectively, of the total evaluated (Table 1). In relation to the sanitization of the vegetables at the moment of harvesting, $54.2 \%$ of producers performed it; however, $100 \%$ of them did not carry out the individual sanitization with chlorinated water, evidenced by the absence of high impact measures in the reduction of $\mathrm{TC}, \mathrm{TtC}$, and $\mathrm{IPE}$ in the vegetables (Jesus et al., 2015). Only $8.33 \%$ of the producers still transported the vegetables in non-sanitized wooden

Table 3: Association analysis for the investigated risk factors in the 24 producers and the respective P-values for thermotolerant coliforms (TtC)

\begin{tabular}{|c|c|c|c|c|}
\hline & \multirow{2}{*}{ Category } & \multirow{2}{*}{$\begin{array}{c}\text { Number } \\
\text { of producers }\end{array}$} & \multicolumn{2}{|l|}{ TtC } \\
\hline & & & $>0.3(\%)$ & p \\
\hline \multirow{2}{*}{ Use of non-treated organic fertilizer } & No & 16 & 25 & \multirow{2}{*}{0.099} \\
\hline & Yes & 08 & 62.5 & \\
\hline \multirow{2}{*}{ Use of reservoir or river water for irrigation with a close septic tank } & No & 19 & 36.8 & \multirow{2}{*}{1.000} \\
\hline & Yes & 05 & 40 & \\
\hline \multirow{2}{*}{ Use of reservoir or river water for irrigation where there is release of wastewater } & No & 16 & 56.3 & \multirow{2}{*}{0.009} \\
\hline & Yes & 08 & 0 & \\
\hline \multirow{2}{*}{ Absence of sanitization in the harvesting of vegetables } & No & 13 & 15.4 & \multirow{2}{*}{0.033} \\
\hline & Yes & 11 & 63.6 & \\
\hline \multirow{2}{*}{ Absence of individual sanitization of vegetable with chlorinated water } & No & 24 & 36.8 & \multirow{2}{*}{1.000} \\
\hline & Yes & 00 & 40 & \\
\hline \multirow{2}{*}{ Transport in non-sanitized wooden box } & No & 22 & 31.8 & \multirow{2}{*}{0.130} \\
\hline & Yes & 02 & 100 & \\
\hline \multirow{2}{*}{ Transport in non-sanitized plastic box } & No & 05 & 60 & \multirow{2}{*}{0.326} \\
\hline & Yes & 19 & 31.6 & \\
\hline \multirow{2}{*}{ Transport in a truck with a wooden truck body } & No & 14 & 50 & \multirow{2}{*}{0.210} \\
\hline & Yes & 10 & 20 & \\
\hline
\end{tabular}

Table 4: Association analysis for the investigated risk factors in the 24 producers and the respective P-values for the intestinal parasite eggs (IPE)

\begin{tabular}{|c|c|c|c|c|}
\hline & \multirow{2}{*}{ Category } & \multirow{2}{*}{$\begin{array}{c}\text { Number } \\
\text { of producers }\end{array}$} & \multicolumn{2}{|l|}{ IPE } \\
\hline & & & $>0(\%)$ & $\mathbf{p}$ \\
\hline \multirow{2}{*}{ Use of non-treated organic fertilizer } & No & 11 & 31.3 & \multirow{2}{*}{1.000} \\
\hline & Yes & 13 & 37.5 & \\
\hline \multirow{2}{*}{ Use of reservoir or river water for irrigation with a close septic tank } & No & 19 & 26.3 & \multirow{2}{*}{0.289} \\
\hline & Yes & 05 & 60 & \\
\hline \multirow{2}{*}{ Use of reservoir or river water for irrigation where there is release of wastewater } & No & 16 & 37.5 & \multirow{2}{*}{0.667} \\
\hline & Yes & 08 & 25 & \\
\hline \multirow{2}{*}{ Absence of sanitization in the harvesting of vegetables } & No & 13 & 54.5 & \multirow{2}{*}{0.082} \\
\hline & Yes & 11 & 63.6 & \\
\hline \multirow{2}{*}{ Absence of individual sanitization of vegetable with chlorinated water } & No & 24 & 42.1 & \multirow{2}{*}{0.130} \\
\hline & Yes & 00 & 40 & \\
\hline \multirow{2}{*}{ Transport in non-sanitized wooden box } & No & 22 & 31.8 & \multirow{2}{*}{1.000} \\
\hline & Yes & 02 & 50 & \\
\hline \multirow{2}{*}{ Transport in non-sanitized plastic box } & No & 05 & 35 & \multirow{2}{*}{1.000} \\
\hline & Yes & 19 & 25 & \\
\hline \multirow{2}{*}{ Transport in a truck with a wooden truck body } & No & 14 & 28.6 & \multirow{2}{*}{0.673} \\
\hline & Yes & 10 & 40 & \\
\hline
\end{tabular}

Rev. Ceres, Viçosa, v. 65, n.1, p. 093-098, jan/fev, 2018 
boxes, while $16 \%$ already made use of plastic boxes for transport. Despite the progress in substituting wooden boxes for plastic ones, only five producers (or 20.84\%) sanitized the plastic boxes. In relation to the type of truck body used to transport the vegetables, the majority (58.34\%) used the box model, which reduces the risk of contamination and loss of vegetable leaves by bacteria of the coliform group (Lourenço \& Katz, 2010).

In relation to the presence of $\mathrm{TC}$ in the vegetables, they were detected in $24(100 \%)$ of the samples, values which oscillated from 0.3 to $240 \mathrm{CFU} / \mathrm{mL}$. As for the investigation of $\mathrm{TtC}$, they were detected in 23 samples (95.83\%), with values oscillating from 0.3 to $46 \mathrm{CFU} / \mathrm{mL}$. Despite the broad numerical variation of the $\mathrm{TtC}$ found in the samples, this result is of utmost importance in public health due to the potential of these foods as sources of infections and foodborne infections (Martins et al., 2010)

In the correlation analysis with the presence of $\mathrm{TtC}$, there was association for the risk factor use of reservoir water where there was release of wastewater and absence of sanitization of the vegetables at the moment of harvesting (Table 3). The results obtained in this work corroborate those obtained by Santos et al. (2010), who studied the hygienic and sanitary quality of vegetables and irrigation water in Salvador-BA, Brazil, and detected unsatisfactory conditions of the investigated areas and the elevated number of vegetables and the water used for their irrigation, which presented contamination by $\mathrm{TC}$ and $\mathrm{TtC}$. Such a result was also confirmed by Mattos et al. (2009), who affirmed that the microbiological contamination in vegetables is due to the use of contaminated water for irrigation.

For the investigation of IPE, these were found in eight samples (33.33\%), with values which oscillated from one to 100 eggs; however, a significant statistical association with the investigated risk factors was not detected (Table 4). Nevertheless, Ferreira et al. (2013), who evaluated the quality of water for irrigation in Teresópolis - RJ, Brazil, found the presence of IPE in $23.82 \%$ of the investigated samples. Nascimento \& Alencar (2014), who investigated 24 vegetable samples in Natal - RN, Brazil, detected parasitic forms in $41.7 \%$ of the samples. More elevated frequencies of IPE in vegetables $(60 \%)$ were detected by Oliveira \& Perez (2014) both in those with or without sanitization.

\section{CONCLUSIONS}

In the conditions under which this work was carried out, it was possible to conclude that:

Total coliforms were found in $100 \%$ of the investigated vegetable samples and thermotolerant coliforms were detected in $95.83 \%$.

Intestinal parasite eggs were found in $33.33 \%$ of the samples, with values that oscillated from 01 to 100 eggs, but there was no significant statistical association for the investigated risk factors.

There was a significant statistical association for the risk factor use of reservoir water, in which there is the release of wastewater and absence of sanitization of the vegetables at the moment of harvesting in relation to the presence of thermotolerant coliforms.

\section{ACKNOWLEDGEMENTS}

We thank the Pró-Reitoria de Pesquisa e Inovação do Instituto Federal de Educação, Ciência e Tecnologia de São Paulo and the National Council for Scientific and Technological Development (CNPq), for the financial support given to the project.

\section{REFERENCES}

Beraldo RM \& Farache Filho A (2012) Bacteriological quality of irrigation water from vegetable gardens in the municipalities of Araraquara, Boa Esperança do Sul and Ibitinga, SP. Alimentos e Nutrição Araraquara, 22:345-350.

Carvalho JB, Nascimento ER \& Ribeiro VR (2003) Presença de ovos de helmintos em hortaliças fertilizadas com lodo de lagoa de estabilização. Revista Brasileira de Análises Clínicas, 35:101-103.

Costa CC \& Oliveira DS (2011) Identificação dos consumidores de hortaliças da feira livre de Pombal-PB: aspectos socioeconômicos e culturais. Revista Verde de Agroecologia e Desenvolvimento Sustentável, 6:56-60.

Costa CC, Araújo EA, Barbosa JWS, Gama KV, Sousa FQ \& Santos DP (2011) Extensão universitária na produção de hortaliças da comunidade Várzea Comprida dos Oliveiras em Pombal-PB. Informativo Técnico do Semiárido, 4:19-22.

Ferreira AP, Horta MAP \& Pereira CRA (2013) Qualidade higiênico-sanitária das águas de irrigação de estabelecimentos produtores de hortaliças no município de Teresópolis, RJ. Revista Uniandrade, 13:15-29.

França BR, Bonnas DS \& Silva CMO (2013) Qualidade higiênico sanitária de alfaces (Lactuca sativa) comercializadas em feiras livres na cidade de Uberlândia, MG, Brasil. Bioscience Journal, 30:458-466.

Hoffman WA, Pons JA \& Janer JL (1934) The sedimentationconcentration method in Schistosomiasis mansoni. Puerto Rico Journal of Public Health and Tropical Medicine, 9:281-298.

Jesus C, Scherer A \& Fassina FP (2015) Avaliação do processo de higienização de vegetais folhosos em uma unidade de alimentação e nutrição. Uningá, 21:05-09.

Lourenço JO \& Katz L (2010) Estudo dos diversos índices de perdas no manuseio e transporte de verduras, legumes e frutas relacionadas à gestão logística. Tekhne e Logos, 2:01-16.

Machado DC, Maia CM, Carvalho ID, Silva NF, Dantas MC, Porfírio AB \& Serafini AB (2006) Microbiological quality of organic vegetables produced in soil treated with different types of manure and mineral fertilizer. Brazilian Journal Microbiology, 37:538-544.

Martins AGLDA, Nascimento AR, Mouchrek Filho JE, Mendes Filho NE, Souza AG, Aragão NE \& Silva DSVD (2010) Antibacterial activity of essential basil oil against serogroups of enteropathogenic Escherichia coli isolated from lettuce. Ciência Rural, 40: 1791-1796. 
Mattos LM, Moretti CL, Moura MA, Maldonade IR \& Silva EYY (2009) Produção segura e rastreabilidade de hortaliças. Horticultura Brasileira, 27:408-413.

Nascimento ED \& Alencar FLS (2014) Eficiência antimicrobiana e antiparasitária de desinfetantes na higienização de hortaliças na cidade de Natal-RN. Ciência e Natura, 36: 92-106.

Oliveira AAB \& Perez LF (2014) Contaminação de enteroparasitas em folhas de alface. Revista Eletrônica Novo Enfoque, 18:109-124.

Oliveira RM, Begotti IL, Rosa G, Vieira GFP, Merlini LS \& Messa V (2014) Avaliação parasitológica de alfaces (Lactuca sativa) comercializadas no município de Umuarama, Paraná, Brasil. Revista Brasileira de Higiene e Sanidade Animal, 8:01-12.

OMS - Organização Mundial de Saúde (1991) Pranchas para diagnóstico de parasitas intestinais. São Paulo, Editora Santos. 20p.

Santos YO, Almeida RCC, Guimarães AG \& Almeida PF (2010) Hygienic sanitary quality of vegetables and evaluation of treatments for the elimination of indigenous E. coli and E. coli O157:H7 from the surface of leaves of lettuce (Lactuca sativa L.). Revista Ciência e Tecnologia de Alimentos, 30:1083-1098.
Silva PIAP, Carvalho JS, Moura CLF, Dominguez GF, Carvalho MRB, Orge MD \& Vale VLC (2011) Condições sanitárias e ambientais das águas de irrigação de hortas e de Lactuca sativa (alface) nas cidades de Catu e Alagoinhas-Bahia, Brasil. Revista de Ciências Médicas e Biológicas, 9:194-199.

Silva LP, Santos SV, Ludwig KM, Montenote MC \& Silva RMG (2014) Avaliação parasitológica em amostras de alfaces (Lactuca sativa var. crispa) comercializadas no Município de Quatá, São Paulo, Brasil. Bioscience Journal, 30:1252-1258.

Silva N, Junqueira VCA \& Silveira NFA (2007) Manual de métodos de análises microbiológicas de alimentos. $3^{\mathrm{a}}$ ed. São Paulo, Livraria Varela. 317p.

Teixeira LJQ, Kluge JMDAT, Silva NM \& Reis FP (2006) Hábitos de consumo de frutas entre estudantes da Universidade Federal de Viçosa. Revista Ceres, 53:366-373.

Vanderzant C \& Splittstoesser DF (1992) Compendium of methods for microbiological examination for foods. $3^{\mathrm{a}}$ ed. Washington, American Public Health Association. 1219p.

Zar JH (1999) Biostatistical analysis. $4^{\text {th }}$ ed. Upper Saddle River, Prentice Hall. 663p. 